\title{
Expression of Gag and Pol from reconstructed HERV-FC1, associated with multiple sclerosis
}

\author{
Kari K Nissen ${ }^{1 *}$, Finn S Pedersen², Bjørn A Nexø ${ }^{1}$ \\ From Frontiers of Retrovirology 2011 \\ Amsterdam, The Netherlands. 3-5 October 2011
}

\section{Background}

Though the etiology of Multiple Sclerosis (MS) is still obscure, Human Endogenous Retroviruses (HERVs) have long been suspected to be involved [1]. Functional studies have backed this theory, and recently our group provided more direct genetic evidence for association of MS with a provirus located on chromosome X, HERVFc1 [2]. An association with the retroviral restriction factor TRIM5 was also found.

The HERV-Fc1 sequence contains the general retrovirus structure of LTR-elements and the three genes gag, pol and env. The env gene seems intact with an open reading frame (ORF). The gag ORF is terminated by two stop codons, compared to the common single stop in exogenous retroviruses. The pol frame is interrupted by a frameshift mutation and a premature stopcodon; a polymorphic C-repeat in the pol gene represents a second frameshift in some persons.

HERV-Fc1 is only sparsely characterized, and we therefore aimed to investigate this provirus, especially in relation to its potential involvement in autoimmunity.

\section{Materials and methods}

The HERV-Fc1 gag and gag-pol genes were cloned into expression vectors in a CMV-promoter context. Due to lack of commercial antibodies, the genes were fused to C-terminal 6xHis-tags. For one set of vectors, the pol reading frame was restored by point mutations of the nucleotides disrupting ORF. All clones were fully sequenced to ensure correct sequence, before cellular expression. Protein expression was determined by Western blotting and immunohistochemistry.

${ }^{1}$ Department of Biomedicine, Aarhus University, DK-8000 Aarhus C, Denmark Full list of author information is available at the end of the article

\section{Results}

Expression of both Gag and GagPol polyproteins was detected. Both high molecular weight (>140kDa) GagPol and lower $(\sim 40 \mathrm{kDa})$ presumed íntegrase protein was found. A longer stretch of the 5'UTR region preceding gag was necessary for expression; no protein expression was obtained when only including a few nucleotides before the ORF. Inclusion of the 5'LTR region inhibited the expression.

Upon expression, pelletable Fc1 Gag could be detected in the culturing media. This cellular exclusion seem specific, since GFP-6xHis fusion-protein expressed from a similar vector and endogenous Beta-tubulin could not be detected. Reverse Transcriptase activity has so far not been detected from the gag-pol constructs.

\section{Conclusion}

The HERV-Fc1 gag gene has potential for immediate expression; this expression is dependent on the 5'UTR region of gag. Expression of Fc1 GagPol polyprotein could be achieved upon only three point mutations, with read-through of one stop-codon between gag and pol. Cellular exclusion of Gag suggests particle formation and export.

These vector constructs can be used in future characterization of HERV-Fc1, e.g. tropism determined by host restriction factors, drug sensitivity etc.

\section{Author details}

${ }^{1}$ Department of Biomedicine, Aarhus University, DK-8000 Aarhus C, Denmark. 2Department of Molecular Biology and Genetics, Aarhus University, DK-8000 Aarhus C, Denmark.

\section{Published: 3 October 2011}

\section{References}

1. Antony JM, Deslauriers AM, Bhat RK, Ellestad KK, Power C: Human endogenous retroviruses and multiple sclerosis: innocent bystanders or disease determinants? Biochim Biophys Acta 2011, 1812(2):162-176. 
2. Nexø BA, Christensen T, Frederiksen J, Møller-Larsen A, Oturai AB, et al: The etiology of multiple sclerosis: genetic evidence for the involvement of the human endogenous retrovirus HERV-Fc1. PLOS ONE 2011, 6(2):e16652.

doi:10.1186/1742-4690-8-S2-P56

Cite this article as: Nissen et al:: Expression of Gag and Pol from

reconstructed HERV-Fc1, associated with multiple sclerosis. Retrovirology

2011 8(Suppl 2):P56.

Submit your next manuscript to BioMed Central and take full advantage of:

- Convenient online submission

- Thorough peer review

- No space constraints or color figure charges

- Immediate publication on acceptance

- Inclusion in PubMed, CAS, Scopus and Google Scholar

- Research which is freely available for redistribution

Submit your manuscript at www.biomedcentral.com/submit 